\title{
A review on the calculation of cost of capital
}

\author{
E. Chuke Nwude*
}

Department of Banking and Finance, Faculty of Business Administration, University of Nigeria Nsukka, Nsukka 410001, Nigeria

\section{ART ICLE INFO}

\section{Article history:}

Received 10 May 2016

Received in revised form

5 September 2016

Accepted 15 September 2016

\section{Keywords:}

Cost of equity

Cost of preference stock

Cost of debt

WACC

After-tax cost of capital

Before-tax cost of capital

Capital structure

\begin{abstract}
A B S T R A C T
As cost of capital is generally accepted as an essential element of investment appraisal, its calculation must be undertaken with care and failure to do so could lead to adverse consequences for the business. When one examines some standard financial management textbooks treatments of how to calculate cost of capital from the firms' perspectives, one finds apparent inconsistencies and, sometimes, outright errors. Many models to find the cost of capital has been developed and applied in several situations in the operations of firms. Consequently, this study examined cost of capital, the latest definitions and latest conceptions surrounding it. Archival research was adopted. It was confirmed that since the short term debts are temporary and offset by cash and marketable securities held by the firm they are excluded from computation of cost of capital. The findings indicate that there different methods of computing the constituents parts of cost of capital as the need of the situation on ground warrants. However, in computing the weighted cost of debt capital any method that includes the conversion of debt before-tax, $k_{d}$ to cost of debt after-tax, $k_{d}(1-T)$ is accurate. Likewise the overall cost of capital is the weighted average cost of all the sources of funds that form the capital structure of the firm. This conforms to what obtains in more recent studies on measurement of cost of capital.
\end{abstract}

(C) 2016 The Authors. Published by IASE. This is an open access article under the CC BY-NC-ND license (http://creativecommons.org/licenses/by-nc-nd/4.0/).

\section{Introduction}

Firms obtain capital from various sources to run the business. Capital refers to any form of wealth or resource useful in the creation of more wealth or resources. Cost of capital on the other hand is the minimum rate of return that should be earned on an investment to maintain net worth. Cost of capital can be looked at from both financing and investment sides. On financing side it is defined as the totality of charges on funds raised by the user of the funds which at same time stands as the minimum return expected by the supplier of the funds. It is the minimum return the user ought to make on his investments to earn the cash flows out of which the funds suppliers can be paid their expected returns. On investment side, it is the opportunity cost of funds which the investors hope to get somewhere else which if not gained from the present investment the investment is considered unworthy. In this light it is the discount rate used to discount cash flows

\footnotetext{
* Corresponding Author.

Email Address: chuke.nwude@unn.edu.ng (E. C. Nwude)

http://dx.doi.org/10.21833/ijaas.2016.08.016

2313-626X/@ 2016 The Authors. Published by IASE.

This is an open access article under the CC BY-NC-ND license

(http://creativecommons.org/licenses/by-nc-nd/4.0/)
}

from investments in the discounted cash flow methods of investment appraisal. If the cost of capital is less than the expected return from the investment, the investment would be a good deal and would generate a good net value. In any business set-up the cost of fund should be ascertained, if not for any other reason, at least to know when there is positive return on the usage of such fund. It will be bad corporate financial management to invest in project that would fetch returns lower than the cost of fund.

Cost of capital is one of the most discussed and disputed topics in the finance theory because it has applications in many decisions in the firm. For instance, it is used to evaluate capital projects, determine optimum financing mix, design financial and capital structures of firms, evaluate the performance of top management and make dividend decision. Financial experts express conflicting opinions as to the way it can be measured and its very vital role in financial decision-making. Cost of capital is useful as a standard for evaluating investment decisions, designing a firm's debt policy, and appraising the financial performance of top management. The cost of capital serves as the cut-off or hurdle rate which must be cleared by all acceptable projects. It is therefore important that a correct definition and measurement of it are made 
because its use automatically sets a limit on the size of a firm's total investment budget. It also defines the minimum required rate of return on new investments. A firm's capital budgeting decisions are greatly influenced by the cost of capital used to discount the earnings streams. Thus the acceptance of a project with a rate of return below its cost of capital will decrease its overall market value. Many decisions in the firm such as leasing, bond refinancing/refunding, working capital policy and so on derive their legitimacy largely from an accurate estimation of the cost of capital.

The risk differences in different sources of raising capital and the contractual agreements between the firm and investors generate different forms of cost of capital. This led to the classification of cost of capital into specific cost such as cost of equity capital, cost of preference shares, cost of bonds, and cost of any other financing instruments. It could also be weighted average cost of capital which is essentially the totality or overall cost of funds for an entity. It could as well be marginal cost of fund which is the incremental cost of capital when new funding instrument is added. Clearly stated, the combined cost of all sources of capital is called overall cost of capital or weighted average cost of capital (WACC) and this is regarded as the firm's cost of capital.

The burning issue in this study that agitates the mind of the researcher is the ambiguity that trails measurement of the various constituents of cost of capital and how can each be ascertained in practice? Atrill (2006) suggested that as the cost of capital is an essential element of investment appraisal, its calculation must be undertaken with care and failure to do so could lead to adverse consequences for the business. Consequently the objective of the paper is to survey the recent development in the measurement of costs of capital constituent parts of cost of capital, the latest definitions and latest conceptions surrounding it. The salient feature of the paper is to provide a straight forward treatment of this important topic in a non-technical way. This paper has been segregated into five major sections. Section one introduced the motives that propelled the research. The structure for the rest of paper is as follows. In section 2, the author reviews some theoretical and empirical studies and demonstrates the application of the techniques. Section 3 explains the methodology of the study. Findings from the study are presented in Section 4. Finally, in section 5, the author presents some concluding remarks.

\section{Literature review}

According to Martin et al. (2005), cost of capital is the rate that the firm must earn on its investments if it wants to keep the investors satisfied by giving them their required rate of return. Block and Hirt (2000) and Schall (1973) stated that cost of capital represents the overall cost of financing to the firm, which is normally used as the discount rate in analysing an investment and it is usually obtained from the mix of various permanent sources of financing the firm. It is a composite cost of debt and equity funds. Brealey et al. (2007), Besley and Brigham (2008), Franks and Scholefield (1979) and Moshe (1987) opined that cost of capital is the minimum acceptable rate of return when a firm expands by investing in average risk project. Achuchaogu (2002), Akinsulire (2006), Maness (2007), Mpamugo (2003), Njoku and Jumbo (2003), Nwude (2003), and Onyendi (2004) argued that cost of capital of a firm represents a hurdle rate that a project's return must surpass in order to be profitable. Kurfi (2003), Babatunde (2008), Emekekwue (2002), and Nwankwo (2002) regarded cost of capital as that amount of earnings which must be sustained in order to ensure that the market value of equity stock does not drop. Arnold and Hope (1990), Schall (1973), and Adeniji (2004) agreed that cost of capital is the interest rate or discount rate to discount an investment's future cash flows to their equivalent present value (PV) but there is conflicting view on just how it should be measured. Adetifa (2005) believed that cost of capital of a given company is the price being paid by the company to the stakeholders for being allowed the use of their capital. For example, the cost of debt is the interest payable to the debt holders; the cost of preference stock is the dividends payable to the preference stock holders, etc. Adetifa (2005) concluded that cost of capital includes opportunity cost of capital invested, rate of inflation, risk premium and investors' return preference. Olowe (2008) saw cost of capital as the cost of funds raised by a company and the return expected by investors that put funds into the company. Olowe (2008) indicated that cost of capital is the minimum return that a company ought to earn on its investments to produce the cash flows out of which investors can be paid their returns. Etzel (2003) suggested it is the minimum return that is required on a new investment. Uzoka (2006) defined it as the overall or average required rate of return on the aggregate of the various investment projects. Pandey (1999) posited that cost of capital is the minimum acceptable required rate of return which compensates for time and risk in the use of the capital. The firm's cost of capital can be adjusted upward or downward to account for the differential riskiness of investment projects. That is an investment project's required rate of return may be equal to the firm's cost of capital plus or minus a risk adjustment factor. It is stated that cost of capital is the cost of a company's funds both debt and equity. From investors' point of view, it is the expected return on a portfolio of all the company's existing securities. It is used to evaluate new projects of a company as it is the minimum return that investors expect for providing capital to the company, thus setting a benchmark that a new project has to meet. It goes further to state that cost of capital is the overall percentage cost of the funds used to finance a firm's asset.

Ross et al. (1996), Damodaran (2001), Atrill (2006), Arnold (2008), Berk and DeMarzo (2011), and Banerjee (2009) refered to cost of capital as 
overall cost of capital of a firm which actually is the weighted average cost of capital (WACC) of various long-term sources. Arnold (2008) stated that short term debts are excluded from WACC computation because they are temporary and also offset by cash and marketable securities held by the firm. Capital structure with the long term funding mix is used. As a gauge, the debt/Equity mix is presumed to have reached its optimum level wherein the average cost of capital is found to be the best minimum possible. Cost of capital is also seen as the expected rate of return that the market requires in order to attract funds to a particular investment. If a business is all equity financed, then the cost of capital is the return which the shareholders of the business expect to receive for the risk they have taken in investing in the business. That rate of return should be the sum of the interest cost plus the amount of profit that the business should earn for its equity source of capital, in order to justify the use of the equity capital during the period. The WACC can be broken down into its various components also called the specific costs or explicit costs. The specific or component costs of capital include cost of equity and cost of debt.

\subsection{Cost of equity capital}

The term "cost of equity" is simply the opportunity cost of foregone alternative investments by ordinary shareholders. It is the yield that takes account of both the dividend income and the future growth in capital value. It is the minimum required return on the funds contributed by ordinary shareholders bearing in mind that their investments run into perpetuity. Banerjee (2009) stated that cost of equity are the minimum rate of return that must be earned on equity capital in its capital structure. Olowe (1998) and Brealey et al. (1995) stated that the cost of equity is the minimum rate of return that must be earned on the equity portion of an investment. Pandey (1999) stated that the cost of capital of an all-equity financed firm is simply equal to the ordinary shareholders' required rate of return. The required rate of return is market determined and established by the actions of competing investors in the capital market because the market price of securities is a function of the return expected by investors. The demand and supply forces work in a way that equilibrium rates are established for various securities. The cost of retained earnings is the opportunity cost of dividend forgone by equity holders.

On the estimation of cost of equity the CAPM is commonly used to estimate expected return on equity but for steady-growth companies, it may also make sense to use the constant-growth discounted cash flow model. It is stated that the use of CAPM offers quite a robust estimate of the cost of equity assuming the equity market risk premium (Rm-Rf) is known. However, its use pretty much necessitates a rate of return history of the concerned firm in order to estimate the betas. According to Banerjee (2009), Berk and DeMarzo (2011) beta is the responsiveness of the expected return on a share to the market return. They posit that beta can be estimated from the Covariance of the particular stock and that of the market. A non-beta alternative or the beta-free way to estimate $\mathrm{Ke}$ is the Gordon dividend discount model $(D D M)$ where $\mathrm{Ke}=(\mathrm{D} 1 / \mathrm{Po})+\mathrm{g}$. In this sense, all one need is information on the next period dividend, current price and the growth rate of dividends. Note that D1=Do $(1+\mathrm{g})$. Some studies agreed that the cost of equity could be estimated by means of the dividend valuation model (DVM) because the DVM relates the market value of shares to expected future dividends on the shares. Among them is Pandey (1999) who stated that the most valid measure of the cost of equity is given by the dividend valuation model (DVM). He also points out that the DVM has limited application in practice because it assumes that the dividend per share will grow at a constant rate, $g$, forever and that the $g$ should be less than the cost of equity, Ke. This means that the DVM cannot be applied to those companies which are not paying any dividends, or whose dividend per share is growing at a rate higher than $\mathrm{Ke}$, or whose dividend policies are highly volatile. In the case of CAPM, the only condition for its use is that the company's share is quoted on the stock exchange and all its variables are market determined except beta that is determined by statistical methods. According to Brealey et al. (1995), Ross et al. (1996), Pandey (1999), Damodaran (2001), Berk and DeMarzo (2011) the market value of equity should be used in estimating its cost and WACC because that is what reflects the investors' perception of the company in terms of future investment opportunities and prospects.

Various ways cost of equity can be ascertained include the Earnings/Market price ratio (E/P), dividend growth model (DGM), Earnings growth model (EGM), and Capital asset pricing model (CAPM). From Banerjee (2009), on E/P ratio, $\mathrm{Ke}=$ earnings per share divide by current market price per share = EPS/CMPPS. The assumptions here are 1 . That the market price per share (MPPS) is influenced only by variations in earnings of the firm. 2 . The constant growth rate $g$ of future earnings can be expressed as an average. With the DGM, ke $=[D$ $(1+\mathrm{g}) / \mathrm{MPPS}]+\mathrm{g}$. The $\mathrm{g}$ here represents the growth rate in dividend. The assumption under DGM is that income will grow at a constant compound rate and $g$ will be constant. DGM may be used reliably in firms in which dividend per share (DPS) flow is relatively certain. Where the $g$ is not constant over time, then past trend in EPS expressed as a percent may be used as growth rate $\mathrm{g}$ in dividend, but this cannot work if DPS growth rate is not equal to EPS growth rate. The EGM gives ke = [EPS/CMPPS $]+\mathrm{g}$ where $g$ represents growth rate in earnings. EGM is usually adopted because it used to be extremely difficult to get growth rate in dividend due to arbitrary nature of fixing DPS by firms. The growth rate in earnings is easier to get. Again cost of capital primary objective is to serve as a hurdle rate for investment decision for better earnings. Estimate of $\mathrm{g}$ can be done using 
either $\mathrm{g}=[\text { Latest Dividend/Earliest Dividend }]^{1 / \mathrm{n}_{-} 1}$ or Gordon's model of $\mathrm{g}=\mathrm{br}$ where $\mathrm{b}$ represents retention rate while $r$ represents equity rate of return. In the first formula for $\mathrm{g}$, it is assumed that average past growth rate in DPS will continue unchanged in the future. Another fear here is that past growth rate g may not be reflected in the future growth rate of dividend. Banerjee (2009) and Ross et al. (1996) stated that in using the Gordon's model the following assumptions hold, 1 . The firm must have all-equity financed capital structure. 2. Retained earnings are the only source of additional funding. 3. Constant proportion of the earnings is retained each year for reinvestment. 4. Projects financed by retained earnings produce a constant annual return.

\subsection{Cost of debt}

There are explicit cost and implicit cost of debt finance. The explicit cost is the rate of interest that bondholders demand. The higher the percentage of borrowing the higher the rate of interest bondholders would demand. The implicit cost is the increase in the required rate of return on equity as a result of further borrowing. The higher the percentage of borrowing the higher the risk of the common stock as the company has to pay out more interest before equity holders get a balance of the cash flow and the higher the rate of return that would be demanded by equity holders. These two costs of debt finance must be recognized in estimating the WACC. In estimating the specific cost of each source of capital in the capital structure Olowe (1998), Brealey et al. (1995), Pandey (1999), explained that that of bonds is the yield to maturity on the bond. The yield to maturity is the discount rate that equates the proceeds from a new issue of debt or the current market price of debt to the discounted cash flows from the debt whether the debt is issued at par, discount or premium. Pandey (1999) and Olowe (1998) stated that when debt is issued at par and redeemed at par, the cost of the debt is simply the coupon rate. The cost varies when the debt is issued at a premium or discount. Olowe (1998) submited that appropriate value to use in estimating the cost of existing debt is the current market value or price of the bond ex-interest, and for new debt, it is the proceeds from new issue of debt.

Arnold (2008) divided debt into traded and untraded. The cost of traded debt which is the one bought and sold in a security market is the rate that equates the sum of the interest stream and the redemption value of the debt. That is, Market Price of debt $=\sum \mathrm{I}(1+\mathrm{Kd})-\mathrm{t}+\mathrm{RV}(1+\mathrm{Kd})-\mathrm{n}$, where $\mathrm{I}=$ annual nominal interest receivable from year1 to $\mathrm{n}$. Kd is the cost of debt being looked for and can be obtained by iterative method. Cost of untraded debt is either the current going interest rate for the risk class or rate being offered on similar tradable debt securities. McDaniel et al. (1996) and Banerjee (2009) suggested that the after-tax cost of redeemable debt issued at a discount or premium is $\mathrm{Kd}=[\mathrm{C}+1 / \mathrm{n}(\mathrm{P}$ -
I)] $(1-\mathrm{t}) / 1 / 2(\mathrm{P}+\mathrm{I})$, where $\mathrm{C}=$ interest amount, $1 / \mathrm{n}(\mathrm{P}-$ I) $=$ amortizes the discount or premium over the life of the debt, $1 / 2(\mathrm{P}+\mathrm{I})=$ average amount outstanding, $\mathrm{P}$ $=$ face value, $\mathrm{I}=$ issue price, $\mathrm{t}=$ tax rate, $\mathrm{n}=$ number of years.. However the model does not take care of the annual compounding or sinking fund payments. After-tax cost of perpetual debt is C(1-t)/Issue Price. Damodaran (2001), Arnold (2008) and Banerjee (2009) reported that the cost of new issue of perpetual preference share is preference dividend/Net proceeds of the issue. Banerjee (2009) maintains that for a redeemable preference share $\mathrm{Kp}$ $=[\mathrm{D}+1 / \mathrm{n}(\mathrm{P}-\mathrm{I})](1-\mathrm{t}) / 1 / 2(\mathrm{P}+\mathrm{I})$, where $\mathrm{D}=$ preference dividend.

\subsection{Weighted average cost of capital (WACC)}

The expected return demanded by investors on a firm's assets is the cost of capital of the firm as well as the investors' required rate of return. It could be obtained from the weighted average cost of capital (WACC) of the specific costs of the respective financing instruments that make up the firm's capital structure. The WACC is the sum of the weighted average of the required rates of return on all the securities issued by the firm. This WACC is equivalent to the weighted average of returns demanded by debt and equity investors. The weights are allocated based on the relative market values of the debts and equity in the capital structure. Hence WACC is the rate of return that new and existing investment must generate in order to provide a fair rate of return to all the investors, both debt holders and equity holders. From Olowe (1998) since investment decisions are financed with long term funds, only long-term funds should be included in the WACC computation. The weight is the proportion of each security in the firm's value based on the market values of the securities and not on their book values. As the firm's capital structure changes with respect to proportions of debt and equity, the expected return for debt-holders and equity holders also change. The WACC is used to discount the aftertax cash flows on new projects that are carbon copies of the firm's existing business. Brealey et al. (1995) posited that the income needed to pay the fair rate of return to debt-holders is rate of interest demanded by them multiply by the amount of money they supplied. The income needed to satisfy the equity holders is the rate of return on equity multiply by the amount of money supplied by equity holders.

Brealey et al. (1995), Weston et al. (1996), Pandey (1999), and Atrill (2006) submited that WACC can be obtained by following this processes, calculate the value of each instrument as a proportion of the firm's value; determine the required rate of return on each instrument, and then calculate the weighted average of these required returns, which stands to be the company's cost of capital. Hence the company cost of capital is the expected rate of return that investors demand from the company's assets and operations based on the 
market values of the financing instruments. Brealey et al. (1995) and Pandey (1999) submited that book values while useful for many other purposes only measure net cumulative historical outlays that do not generally measure market values accurately. They further state that market value measures what investors want from the company and this depends on future profits and cash flows and not on accounting history, which usually reflects money mobilized in the past from shareholder or reinvested by the firm on their behalf. On this basis, market value is usually preferred. Again, since interest payments on debt are deducted from income before tax is calculated, the cost of debt is reduced by the amount of this tax saving hence Kd (1-t)

In investment decisions, the relevant cost of capital is used as a discount rate. The WACC is the relevant cost of capital if in its computation it reflects the marginal cost of capital. The WACC reflects the marginal cost of capital if new funds are raised in such a manner that keeps the optimum capital structure unchanged and incorporates the long term future capital structure and cost. Solomon (1955) in (Pandey, 1999) argued that because a company's capital structure changes only very slowly over time, the marginal cost of new capital should be roughly equal to the weighted average cost of current capital.

If the new project under consideration has business (systemic) risk characteristics different from the company's existing operations and the new funds raised for the new project changes the capital structure and perceived financial risk of the company, then the WACC of the extra or incremental capital known as marginal cost of capital (MCC) should be computed and used as the discount rate. The computation of MCC is similar to the WACC computation with the exception that marginal weights, that is, the proportion of each financing source for the extra funds to the total extra funds raised, are used. Therefore in project evaluation, MCC should be used to evaluate proposals if the capital structure is not optimal (i.e. new capital structure emerges as a result of the new project) and the proposed new project is not homogenous with the existing projects, otherwise use WACC.

Furthermore in estimating a project cost of capital, Pandey (1999) submited that the cost of capital of a project is the minimum acceptable rate of return on the funds committed to the project. Any project that generates exactly the rate of return equivalent to WACC would just break-even. That is, it simply generates just enough cash to satisfy both debt-holders and equity holders. On the other hand, a project that generates a rate of return more than the WACC will have positive NPV. This higher rate of return represents the IRR of the project. Hence whenever IRR is greater than the WACC the investor is advised to move ahead with the investment. Brealey et al. (1995) said that when the expected cash flows are discounted at WACC and the NPV is zero, it means that the project's cash flows are just sufficient to give debt-holders and equity holders the return they require. The WACC is the appropriate discount rate for the cash flows of projects with the same risk carbon copy of the firm's existing business and same percent of debt ratio. It is the rate of return that the firm must expect to earn on its average risk investments in order to provide a fair expected return to all its security holders. In using it as a company-wide benchmark discount rate, it should be judgmentally adjusted upward for unusually more risky projects and downward for unusually less risky or safe ones.

However, Fernandez (2010) pointed out some errors in the computation of WACC due to wrong definition of WACC and suggested the corrections. His viewpoints are as follows. The correct tax rate ( $\mathrm{T}$ ) that should be used every year is the $\mathrm{T}$ that relates the equity cash flow (ECF) and the firm cash flow (FCF) as it is shown in the WACC is: $\left[\mathrm{E}_{t} \mathrm{Ke}_{t+1}+\right.$ $\left.\mathrm{D}_{\mathrm{t}} \mathrm{Kd}_{\mathrm{t}+1}(1-\mathrm{T})\right] /[\mathrm{Et}+\mathrm{Dt}]$. The appropriate values of debt and equity are the ones resulting from the valuation (Equity (E) and Debt (D)). The equity value of a firm is given by the difference between the firm value and the outstanding debt, where the firm value is calculated using the WACC, and the WACC is calculated using the outstanding (market value of) debt. If the firm starts with its current debt and moves towards another capital structure, then a variable WACC (different for each year) should be used, and the current debt should be deducted from the enterprise value. The Enterprise Value $(E+D)$ does not satisfy the time consistency formulae. Fernández (2010) showed that the relationship between the enterprise values of different years is: $\mathrm{E}_{\mathrm{t}}+\mathrm{D}_{\mathrm{t}}=\left(\mathrm{E}_{\mathrm{t}-1}+\mathrm{D}_{\mathrm{t}-1}\right)\left(1+\mathrm{WACC}_{\mathrm{t}}\right)-\mathrm{FCF}_{\mathrm{t}}$. And the relationship between the equity values of different years is: $E_{t}=E_{t-1}\left(1+K e_{t}\right)-E F_{t}$. Considering that WACC/(1-T) is a reasonable return for the company's stakeholders some countries assume that a reasonable return on a telephone company's assets is WACC/(1-T). Obviously, this is not correct. The error will be higher when the wrong formula for the WACC applies especially when the value of debt (D) is not equal to its book value $(\mathrm{N})$ and if the return is multiplied by book values. Fernández (2010) showed that the expression for the WACC when the value of debt (D) is not equal to its book value (N) is WACC $=(\mathrm{E} . \mathrm{Ke}+\mathrm{D} . \mathrm{Kd}-\mathrm{N} \mathrm{r} \mathrm{T}) /(\mathrm{E}+\mathrm{D}) . \mathrm{Kd}$ is the required return to debt and $r$ is the cost of debt.

From the above statements, almost all the authors observed that cost of capital is a composite cost of the individual sources of funds which includes common stock, retained earnings, preferred stock and debt. The overall cost of capital depends on the cost of each source and the proportion that each source represents of all capital used by the firm. Therefore the goal of an individual or business is to limit investment to assets that provide a return that is higher than the cost of the capital that was used to finance those assets. As an opportunity cost, cost of capital is the rate of return that a firm would receive if it invested in a different investment vehicle with similar risk. As a hurdle or cut-off rate, it is the minimum required rate of return, obtained as a weighted average of the cost of debt and equity 
funds, used as a discount rate in capital budgeting and in determining the present value of future cash inflows.

\section{Methodology}

Archival research was engaged in this study in order to find the correct position of the term cost of capital and its appropriate uses. Books and journal articles were heavily relied upon for the study. In each material consulted, efforts were made to gather all the views expressed by the author(s) on the issue of cost of capital and its constituents parts. The researcher critically looked at what constitute cost of new or already existing equity, cost of new or already existing preference capital, cost of new or already existing debt capital, and the overall cost of capital also called the weighted average cost of capital (WACC). Both local and foreign authors were consulted in order to obtain balanced information on the methods of measurement in the domestic and the foreign economies.

\section{Presentation and discussion of results}

Based on the archival researches conducted on the issue of cost of capital the researcher came up with the following definitions and conceptions of cost of capital as follows.

\subsection{Definitions of cost of capital}

Cost of capital can be defined as the expenses incurred in acquiring an amount of money. In percentage terms, it is the amount of expenses incurred in procuring an amount of money, expressed as an annual percentage of that amount of money so obtained. Based on the risk evaluation of each firm, investors will supply new funds to a firm only if it pays them their required rate of return that compensate them for taking the risk of investing in the firm's securities. If indeed, the cost of capital is the required rate of return that the firm must pay to generate funds, it becomes a guideline for measuring the profitability of different investments. When there are differences in the degree of risk between the firm and its divisions, a risk-adjusted discount rate approach should be used to determine their profitability. If the goal of the firm is to remain profitable and to increase value to its shareholders, any use of capital must return at least its cost of capital, and optimally, an amount greater than its cost of capital. Therefore, from the lenders perspective, cost of capital is the minimum return or remuneration required by lenders to induce them to provide funding for an on-going business. From the fund-users point of view, cost of capital is the rate of return that the firm must earn on their investments in order to satisfy the required rates of return of all the firm's sources of financing (including creditors who loan the firm money and owners who purchase shares stock in the company). This rate is a function of the required rate of return for all the firm's sources of financing, the company tax rate, and the floatation cost incurred in issuing new securities. The effect of taxes on the firm's cost of capital is observed in computing the cost of debt since its interest is a tax-deductible expense. The use of debt indirectly decreases the firm's taxes. Therefore since we compute internal rate of Return (IRR) on an after-tax basis, we also compute the cost of debt on an after-tax basis. In completing a security offering, investment bankers and other involved individuals receive a commission for their services. As a result, the amount of capital net of these floatation costs is less than the funds invested by the individuals purchasing the security. Consequently, the firm must earn more than the investors required rates of return to compensate for this leakage of capital. Conclusively, cost of capital is the required rate of return that a firm must achieve in order to cover the cost of generating funds in the market place and a required return.

\subsection{Concepts of cost of capital}

The cost of capital of each component of the capital structure is called specific cost of capital. For instance, the cost of equity capital is the minimum rate of return that a firm must strive to earn with the equity finance portion of its investment in order to have a stable market price for its stocks. Hence cost of capital is the minimum rate of return that must be earned to satisfy the required rate of return of the firm's investors. From the firm's point of view, it is the expected return on a portfolio of all the company's existing securities. It is used to evaluate new projects of a company as it is the minimum return that investors expect for providing capital to the company, thus setting a benchmark that a new project has to meet. The cost of capital can also be defined under the following concepts- explicit, implicit, future, specific and overall cost of capital.

\subsubsection{Explicit cost of capital}

Explicit cost of capital arises only when capital is raised. The explicit cost of capital is the discount rate that equates the present value of the inflows that are incremental to the taking of the financing opportunity with the present value of its incremental cash outflows. Alternatively, explicit cost of capital can be defined as the internal rate of return (IRR) of the cash flows associated with the financing opportunity. Therefore, for any interest bearing obligation, the explicit cost of capital should be the discount rate that equates the present value of the contractual future payments of interest and principal with the net amount of the loan.

\subsubsection{Implicit cost of capital}

Implicit cost arises only when the investor considers alternative uses of the funds raised for 
investment purposes. Implicit cost of capital is the rate of return on alternative investments available to the investor. Alternatively, implicit cost of capital can be defined as the opportunity cost of capital. As an opportunity cost of capital, it is the rate of return that a firm would receive if it invested in a different investment vehicle with similar risk.

\subsubsection{Future cost of capital}

The amount of funds needed to finance a new project is usually determined at the point of decision making. But good financial management dictates that the appraisal of the new project should be done using future cost of capital that will prevail at the time of implementation and not with the historical cost that prevailed during the time of decision making. Therefore, future cost of capital is the real cost of funds during the time of execution of the investment project. The project's internal rate of return (IRR) so obtained at the point of decision making is compared to the expected future cost of funds. If the former is greater than the latter the proposed project is viable and vice versa.

\subsubsection{Specific cost of capital}

Specific cost of capital is the cost of each component source of fund that contributed fund into the total fund of the business, like equity, preference shares, debt, retained earnings sources, etc. It is the rate of return that providers of capital demand to compensate them for both the time value of their money and the risk (Chadwick and Donald, 1995).

\subsubsection{Overall cost of capital}

This is the composite or combined cost of capital of all sources of permanent capital of a business. It is obtained from the sum of the Weighted Average Cost of Capital of all the component sources that made up the capital structure of a business. As a result of the process of obtaining it, Overall Cost of Capital is therefore called the Weighted Average Cost of Capital (WACC). It is the minimum rate of return required on an investment in order to maintain the net worth of a business. This is the cost used in project evaluation when such minimum rate of return is required on an investment. However when there is need to give reward to entrepreneurship, the fourth factor of production, a required rate of return should be added to the WACC to cover the interest of the equity holders. This is where the researcher totally agrees with Fernández (2010) that WACC is a Weighted Average Cost of Capital and a required return. However WACC without the required return is purely a firm's overall cost of capital which can be termed a firm's cost of capital. One important reason why many valuations use WACC without the additional required return is because the required return can be arbitrarily determined rather than through a scientific process.

\subsection{Uses cost of capital}

Cost of capital is the rate of return that justified the wealth maximization objective of the firm. It is very important that one should know the cost of capital being utilized because of the following reasons. As it is the minimum return on an investment to maintain net worth, it serves as a decision criterion in capital budgeting decisionsUnder the net present value method it is used as the discount rate to calculate the present value of future cash flows. Under the internal rate of return method it is used to make accept or reject decision by comparing the cost of capital with the internal rate of return on a given project. A project is accepted when the internal rate of return exceeds the cost of capital. It is helpful in making decisions about methods of financing to be adapted and in designing an optimal capital structure. It helps in profit determination and performance evaluation of management. It helps in financial decision making such as determining the amount of dividend in the face of future funding requirements and working capital policies.

\subsection{Computation of specific costs of capital}

The cost of capital specific to each particular type of capital a business uses is called the specific cost of capital. That is, each class of shares, each class of debt securities will have its own cost. Under mentioned are the models relevant to computation of specific costs.

For the short-term financing instruments, the effective specific cost of each financing instrument can be obtained from the quotient of total expenses incurred divide by the amount of fund obtained, multiply by 100 . For instance, if a borrower was granted a credit facility worth N10million but received only N9.5million after upfront deductions, the effective specific cost is obtained from dividing the sum of the interest charge and upfront charges by N9.5million, but not by N10million. The divisor or the denominator should be N10million only when N10million was received. If the borrower actually wants to make use of N10 million, he should beef up his loan request to an amount that will produce the N10million when the upfront deductions are made, using the model: Amount to borrow is equals to Amount of Financing actually required divide by 1.0 - the rate in decimal of upfront deductions. For the permanent sources of capital such as equity, preference shares, and bonds, the following models apply.

\subsubsection{Cost of equity}

The cost of equity can be computed for existing equity called internal equity and new equity called external equity (i.e. new issue of common shares). Further classification is possible under each class stated above. Each can be categorized into equity without growth and equity with growth. The cost of 
external equity is usually higher than the cost of retained earnings because of floatation costs attached to raising external equity finance. This gives rise to another classification termed equity without floatation cost and with floatation cost. On the whole, under equity, we have four forms of equity namely, equity without growth and without floatation cost (i.e. existing equity), equity with growth and without floatation cost (i.e. existing equity), equity without growth and with floatation cost (i.e. external equity), equity with growth and with floatation cost(i.e. external equity). The cost of equity without growth and without floatation cost (i.e. existing equity) = $\mathrm{d} / \mathrm{mv}$. The cost of equity with growth and without floatation cost (i.e. existing equity) $=[\mathrm{d}(1+\mathrm{g}) / \mathrm{mv}]+\mathrm{g}$. The cost of equity without growth and with floatation cost (i.e. external equity) $=d /(m v-c)$. The cost of equity with growth and with floatation cost (i.e. external equity) $=[d(1+g) /(m v-c)]+g$. In these models, d represents dividend per share, mv represents market value per share ex-dividend, c represents floatation cost per share, and $g$ represents dividend growth rate. If the growth rate (g) is not given, the value can be computed using either the Gordon growth model or dividend growth model. With Gordon Growth model, $g=r b$, where $b=$ retention rate, $r=$ rate of return on equity. Retention rate $=1.0$ - payout rate. Therefore $g=(1.0-$ payout rate) (rate of return on equity). With Dividends Growth model, Earliest Dividend $(1+\mathrm{g})^{\mathrm{n}-1}=$ Latest Dividend, hence $g=[L D / E D]^{1 / n-1}-1$, where $L D$ is latest dividend, ED is earliest dividend and $n$ is number of periods.

\subsubsection{Cost of preference shares}

Just like the equity, dividends on preference share is paid after taxes, hence the cost is not taxadjustable. The cost of irredeemable or perpetual preference shares is the quotient of its dividend per share divide by its market price per share exdividend. If the preference share is a new issue, then issue or floatation costs will be taken into the computation and the model will be the quotient of its dividend per share divide by its market price per share less the floatation cost per share. Where the preference share is redeemable, then the approximate cost of it can be obtained from the model, $\mathrm{Kp}=[\mathrm{Dp}+\{(\mathrm{M}-\mathrm{P}) / \mathrm{n}\}] /[(\mathrm{M}+\mathrm{P}) / 2]$, where $\mathrm{M}=$ Face Value of the debt instrument, $\mathrm{P}=$ Price at which debt was sold or issued, $n=$ number of periods to maturity, $\mathrm{D}_{\mathrm{p}}=$ Periodic cash flows or dividends. For better accuracy, it can be the rate that equates the periodic cash flows and the redemption value to the current market price of preference share. That is, the rate that equates, the current value of the preference capital equals to the sum of the present values of the streams of dividend paid during the holding period plus the present value of the redemption value of the preference capital on maturity. Mathematically stated, it is $\mathrm{Pc}=$ $\sum D_{p} /\left(1+K_{p}\right)^{t}+R V /\left(1+K_{p}\right)^{n}$ for time periods 1 ton.
The $D_{p}=$ Preference dividends per share (net), $\mathrm{RV}=$ redemption value.

\subsubsection{Cost of debt}

The debt can be redeemable debt or irredeemable debt, already issued debt or about-tobe-engaged debt. If the debt is redeemable, it means that in the year of redemption the interest payment will be received by the holder along with the amount repayable on redemption. Therefore, the cost of debt $\left(\mathrm{K}_{\mathrm{d}}\right)$ will be the discount rate that equates the periodic cash flows of interest payments plus the redemption value of the debt to the current market price of debt. Mathematically stated it becomes,

$\mathrm{MV}_{\text {ex-interest }}=\mathrm{I}_{1} /(1+\mathrm{Kd})+\mathrm{I}_{2} /(1+\mathrm{Kd})^{2}+\mathrm{I}_{3} /(1+\mathrm{Kd})^{3}+--\cdot-\cdot-+$ $\mathrm{I}_{\mathrm{n}} /(1+\mathrm{Kd})^{\mathrm{n}}+\mathrm{RV_{ \textrm {n } }} /(1+\mathrm{Kd})^{\mathrm{n}}$.

Statistically reduced we have $\mathrm{MV}_{\text {ex-interest }}=$ $\sum \mathrm{I}_{\mathrm{d}} /\left(1+\mathrm{K}_{\mathrm{d}}\right)^{\mathrm{t}}+\mathrm{RVn} /\left(1+\mathrm{K}_{\mathrm{d}}\right)^{\mathrm{n}}$ where $\mathrm{I}=$ Interest payments in periods $1,2,3$, up to $n$. The $M V_{\text {ex-interest }}$ denotes the market value of the debt after deducting the accrued interest charges on the debt. RV = redemption value at the end of the agreed maturity period.

The discount rate $(\mathrm{kd})$ that equates the two sides of the equation is obtained by iterative method, that is, trial and error method. To obtain a rough estimate of the cost of debt the following procedure is followed:

1. Find the cost of debt as if it were irredeemable debt using $\mathrm{kd}=\mathrm{I} / \mathrm{MV}$

2. Add to (1) above the annualized capital profit expressed as a percentage of average current market value thus; $[(\mathrm{M}-\mathrm{P}) / \mathrm{N}] /[(\mathrm{M}+\mathrm{P}) / 2] \times 100$.

3. Addition of Results of (1) and (2) generates a useful starting discount rate to kick-start the iterative process. That is $\mathrm{kd}=\mathrm{I} / \mathrm{MV}+[(\mathrm{M}-$ $\mathrm{P}) / \mathrm{N}] /[(\mathrm{M}+\mathrm{P}) / 2]$

4. To get the cost, the system of internal rate of return (IRR) would be employed. This would entail getting the Net present value (NPV) of the debt at positive and negative extremes. Then extrapolation method is employed to fix the approximate cost of debt.

In the case of irredeemable debt the future cash flows are simply the interest payments in perpetuity. Therefore the cost of debt is obtained thus: $\mathrm{Kd}=$ $\mathrm{I} / \mathrm{MV}_{\text {ex-interest } \mathrm{X} 100 .}$

Effect of floatation costs on cost of debt: The administrative expenses, legal fees, brokerage, underwriting commission etc. are such costs incurred in the course of issuing debt. Collectively they are referred to as floatation costs. The effects of the flotation cost of an issue are two ways. One is the reduction in the proceeds of the issue available for the issuer's use. Secondly it increases the cost of debt. For example, let the amount of debt to be 'raised be $\mathrm{N} 100$ million and the floatation costs be $5 \%$ of the debt value. The proceeds of the debt issue would have been N100 million if there was no floatation cost. But because of the floatation cost the 
proceeds that will be made available to the issuer of the debt instrument will amount to gross proceeds less the floatation costs. Net proceeds of issue $=$ Gross proceeds - Floatation costs. That is, $\mathrm{N} 100,000,000-5 \%(\mathrm{~N} 100,000,000)=\mathrm{N} 95,000,000$. The cost of debt is determined using the net proceeds of the issue thus: Net proceeds of issue are equal to:

Net Proceeds of the issue $==\sum \mathrm{I}_{\mathrm{d}} /\left(1+\mathrm{K}_{\mathrm{d}}\right)^{\mathrm{t}}+$ $\mathrm{RVn} /\left(1+\mathrm{Kd}_{\mathrm{d}}\right)^{\mathrm{n}}$

where I = After-tax Interest payments on 1, 2, 3,---up to $n, R V=$ Redemption value of the debt, $n=$ terminal period, $\mathrm{Kd}=$ After-tax cost of debt. If it is irredeemable debt the cost of debt is obtained as the quotient of Interest divide by net proceeds of issue. Interest paid on debt is tax deductible. The higher the interest charges, the lower the tax payable. Before-tax cost of debt $=$ the Effective rate on the debt $=\mathrm{k}_{\mathrm{d}}$. After-tax cost of debt $=$ Effective rate adjusted for tax purposes at the applicable tax rate (t). However, the true cost of debt remains the effective rate which is the before- tax cost of debt. This is because the tax benefit of interest deductibility is only available to profitable firms paying taxes. An unprofitable firm does not pay any taxes. Therefore it would not gain any tax benefit associated with interest payments. After-tax cost of debt for Redeemable Bond is the discount rate that equates, $\quad M V_{\text {ex-interest }}=\sum \mathrm{I}_{\mathrm{d}}(1-\mathrm{t}) /\left(1+\mathrm{K}_{\mathrm{d}}\right)^{\mathrm{t}}+$ $\mathrm{RVn} /\left(1+\mathrm{K}_{\mathrm{d}}\right)^{\mathrm{n}}$ where t represents the tax rate.

After-tax Cost of debt for Irredeemable bond is $\mathrm{Kd}(1-\mathrm{t})=\mathrm{I}(1-\mathrm{t}) / \mathrm{MV}_{\text {ex-interest }} \mathrm{X} 100$.

\subsection{The weight average cost of capital (WACC)}

WACC is the sum of the weighted costs of all the component sources of funds that make up the capital structure of the firm. It is computed using the sources of funds that constitute the capital structure of the firm. The weights being attached to each source is the proportion of each component source in the capital structure. The WACC is the cost of capital that is used by companies to evaluate investment proposals. Two methods of weighting are in use. One method is market- value based and the second method is book-value based, of the contributions of each component source of funds. The former is more popular than the later especially for quoted companies. When market value based method is used, only one cost of equity can be calculated. This removed the need to estimate a separate cost for retained earnings. Book value based method is ample for unquoted companies because estimates of market values are most likely to be subjective. The WACC can be calculated using either the 4-column method or 5-column method as shown in Tables 1-4.

Table 1: Computation of WACC using the 4-column method

\begin{tabular}{|c|c|c|c|}
\hline 1 & 2 & 3 & 4 \\
\hline Sources of funds & Market Value (MV) & Specific Costs(SC) & Hash Total (HT) \\
\hline Equity & $\mathrm{MVe}$ & ke & MVe(ke) \\
\hline Preference capital & MVp & $\mathrm{kp}$ & $\mathrm{MVp}(\mathrm{kp})$ \\
\hline Debt & $\underline{\mathrm{MVd}}$ & $\operatorname{kd}(1-t)$ & $\mathrm{MVd}[\mathrm{kd}(1-\mathrm{t})]$ \\
\hline Total & $\overline{\mathrm{MV}}$ & & $\sum$ HashTotal \\
\hline \multicolumn{4}{|c|}{ WACC $=\frac{\left.\sum \text { (Hash Total }\right)}{\sum(\mathrm{MV})}$} \\
\hline
\end{tabular}

Table 2: The computation of WACC using the 5-column method

\begin{tabular}{|c|c|c|c|c|}
\hline 1 & 2 & 3 & 4 & $5=3 \times 4$ \\
\hline Sources of funds & Market Value (MV) & Proportion & Specific Costs (\%) & WCC \\
\hline Equity & MVe & $\mathrm{MVe} / \Sigma \mathrm{MV}$ & ke & $\mathrm{MVe} / \sum \mathrm{MV}(\mathrm{ke})$ \\
\hline Preference capital & $\mathrm{MVp}$ & $\mathrm{MVp} / \sum \mathrm{MV}$ & $\mathrm{kp}$ & $\mathrm{MVp} / \sum \mathrm{MV}(\mathrm{kp})$ \\
\hline Debt & $\underline{\mathrm{MVd}}$ & $\underline{\mathrm{MVd} / \Sigma \mathrm{MV}}$ & $\mathrm{kd}(1-\mathrm{t})$ & $\mathrm{MVd} / \sum \mathrm{MV}[\mathrm{kd}(1-\mathrm{t})]$ \\
\hline Total & $\sum \mathrm{MV}$ & $\underline{1.0000}$ & & $\sum \mathrm{WCC}=\mathrm{WACC}$ \\
\hline
\end{tabular}

Therefore WACC can be found as WACC = sum of the products of the proportion of contribution of each source of capital to total capital structure of the firm and its specific cost. That is, WACC $=$ WeKe + $\mathrm{WpKp}+\mathrm{W}_{\mathrm{d}} \mathrm{K}_{\mathrm{d}}(1-\mathrm{t})$, where $\mathrm{We}, \mathrm{Wp}, \mathrm{Wd}=$ proportion of total capital structure supplied by equity, preferred stock, and debt respectively, while Ke, $\mathrm{K}_{\mathrm{p}}$, $\mathrm{K}_{\mathrm{d}(1-\mathrm{t})}=$ specific costs of equity, preferred stock, and after-tax cost of debt respectively. $T$ denotes the applicable tax rate.

To exemplify the above models we assume the following capital structure and the cost of each source of financing for a company.

With the 5-column method the overall or composite cost of capital is obtained from
$0.45(20.28 \%)+0.22(15.25 \%)+0.11(12.75 \%)+$ $0.22(10 \%)=16.09 \%$. It can be seen that WACC is a calculation of a business cost of capital in which each category of source of capital in the capital structure is proportionately weighted and the cost of each is multiplied by its proportional weight, after which the products are summed up to give WACC. Mathematically, it is WACC $=\frac{E}{V}(\mathrm{Ke})+\frac{P}{V} K p+$ $\frac{D}{V} K d(1-t)$ which is also equivalent to $=$ WeKe $+\mathrm{WpKp}+\mathrm{WdKd}(1-\mathrm{t})$. The $\mathrm{V}, \mathrm{E}, \mathrm{P}$, and D are usually the market values of the entire firm's capital structure, equity, preference shares, and debt respectively, while $\mathrm{Ke}, \mathrm{Kp}, \mathrm{Kd}(1-\mathrm{t})$ are the specific costs of equity, preference shares and after-tax cost 
of debt. The E/V, P/V, D/V are the proportions of financing that came from equity, preference shares, and debt respectively, while $\mathrm{t}$ is the applicable corporate tax rate.

Table 3: With 4-column method

\begin{tabular}{|c|c|c|c|}
\hline Sources & Book Value (N'b) & 20.28 & Hash Total (N'b) \\
\hline Share capital & 40 & 15.25 & 3.112 \\
\hline Retained Earnings & 20 & 12.75 & 1.050 \\
\hline Preferred Stock & 10 & 10.00 & 2.000 \\
\hline Debt & 20 & & 14.437 \\
\hline \multicolumn{2}{|c|}{ WACC $=\frac{\sum \text { (Hash Total) }}{\sum(\mathrm{MV})}$} \\
\hline
\end{tabular}

Table 4: With 5-column method

\begin{tabular}{|c|c|c|c|c|}
\hline Sources & Book Value (N'b) & Specific Costs (\%) & Proportions & 0.45 \\
\hline Share capital & 40 & 20.28 & 0.22 & 9.13 \\
\hline Retained Earnings & 20 & 15.25 & 0.11 & 3.36 \\
\hline Preferred Stock & 10 & 12.75 & 0.22 & 1.40 \\
\hline Debt & 20 & 10.00 & 1.00 & 1.20 \\
\hline
\end{tabular}

From the foregoing, a firm should discount its cash flows with WACC to determine the net present value (NPV) of a project because WACC is the overall minimum required rate of return on the firm as a whole. It is the appropriate discount rate to use for cash flows with risk that is similar to that of the overall firm.

\subsection{Computation of beta}

The use of CAPM requires the expected risk-free rate of return, the beta of the security and the expected risk premium. The risk-free rate is generally approximated by the highly liquid, shortterm government security. In the case of Nigeria, the yield on quarterly government Treasury Bills serves as a proxy for the risk-free rate. For the market return, the average monthly NSE All-share index during the study period is used to approximate the market rate of return. The historical returns from both the asset concerned and the market index are regressed to obtain the beta of the asset. With the beta value or coefficient the cost of equity can be generated using the Capital Asset Pricing Model (CAPM) as propounded by William Sharpe in 1964.

\section{Conclusion}

In summary, cost of capital is the rate the firm must earn for the investors to earn their required rate of return. Types of cost of capital include specific cost, weighted average cost of capital (WACC) and marginal cost. Under the specific cost we have cost of equity, cost of preferred stock and cost of debt including various respective costs of short term financing instruments such as Bills, notes and papers. The cost of debt is the yield to maturity which is the discount rate that equates the proceeds from a new issue of debt or the current market price of debt to the discounted cash flows from the debt whether the debt is issued at par, discount or premium. WACC is the overall cost of capital of a firm which usually serves as hurdle rate or discount rate for capital projects in investment appraisal as well as bench mark for financing decisions. Marginal cost is the incremental cost of mobilizing additional funding. Majority of these concepts of cost of capital are reflected in the works of Alberts and Archer (1973), Alberts and Faerber (1966), Arditti and Pinkerton (1978), Averbach (1979), Beranek (1977), Lewellen (1974), Lister (1983), Miller and Modigliani (1966), Miller and Modigliani (1958), Patterson (1986), Reilly and Wecker (1973), Samuels (1968), Solomon (1955), and Vickers (1970).

From the lenders perspective, cost of capital is the minimum return or remuneration required by lenders to induce them to provide funding for an ongoing business. From the fund-users point of view, cost of capital is the rate of return that the firm must earn on their investments in order to satisfy the required rates of return of all the firm's sources of financing (including creditors who loan the firm money and owners who purchase shares stock in the company). This rate is a function of the required rate of return for all the firm's sources of financing, the company tax rate, and the floatation cost incurred in issuing new securities. The effect of taxes on the firm's cost of capital is observed in computing the cost of debt since its interest is a tax-deductible expense.

\section{References}

Achuchaogu KC (2002). Contemporary Issues in Financial Management. Knowroch, Lagos, Nigeria.

Adeniji N (2004), An insight into management accounting. Value Analysis Consult, Lagos, Nigeria

Adetifa SB (2005). Corporate finance and investment strategy. The Chartered Institute of Bankers of Nigeria, Lagos, Nigeria.

Akinsulire $O$ (2006). Financial management. 4thedtn, Gemosl Nigeria Ltd, Lagos, Nigeria. 
Alberts WW and Archer SH (1973). Some evidence on the effect of company size on the cost of equity capital. Journal of financial and quantitative analysis, 8(02): 229-242.

Archer SH and Faerber LG (1966). Firm size and the cost of externally secured equity capital. The Journal of Finance, 21(1): 69-83.

Arditti FD and Pinkerton JM (1978). The valuation and cost of capital of the levered firm with growth opportunities. The Journal of Finance, 33(1): 65-73.

Arnold G (2008). Corporate financial management. 4ed, FT Prentice Hall, Pearson Education.

Arnold J and Hope T (1990). Accounting for management decisions. Prentice-Hall, UK.

Atrill P (2005). Financial management for decision makers. 4ed, FT Prentice Hall, Pearson Education.

Auerbach AJ (1980). Wealth maximization and the cost of capital. Quarterly Journal of Economics, 2(1):433-446.

Babatunde 00 (2008). A dictionary of Finance. FAY Ventures, Lagos, Nigeria.

Banerjee B (2009). Fundamentals of financial Management. Eastern Economy Edition, PHI Learning, New Delhi, India.

Ben-Horim M (1987). Essentials of corporate finance. Allyn and Bacon Inc, New York, USA.

Beranek W (1977). The weighted average cost of capital and shareholder wealth maximization. Journal of financial and quantitative analysis, 12(01): 17-31.

Berk JB and DeMarzo PM (2011). Corporate finance, the core: Student value edition+ myfinancelab with pearson etext access card. Pearson International edition, Pearson Prentice Hall, New Jersey, USA.

Besley S and Brigham EF (2008). Essentials of managerial finance. Thomson South-Western.

Block SB and Hirt GA (2000). Foundations of Financial Management. McGraw Hill, Irwin, USA.

Brealey RA, Myers SC and Marcus JA (1995). Fundamentals of Corporate Finance. McGraw-Hill, New York, USA.

Brealey RA, Myers SC and Marcus JA (2007). Fundamentals of Corporate Finance. McGraw-Hill, Irwin, USA.

Chadwick and Donald K (1995). Financial Management. Routledge, San Francisco, USA.

Damodaran A (2001). Corporate finance-theory and practice. John Wiley and sons, New York, USA.

Emekekwue P (2002). Corporate Financial Management. African Bureau of Educational Sciences, Brazaville, Congo.
Etzel B (2003). Webster's new world finance and investment dictionary. Wiley, Indianapolis, Indiana, USA.

Fernández P (2010). WACC: Definition, Misconceptions, and Errors. Business Valuation Review, 29(4): 138-144.

Franks JR and Scholefield HH (1979). Corporate Financial Management. Gower Press, London, Britain.

Kurfi AK (2003). Principles of financial management. Benchmark Publishers Limited, Kano, Nigeria.

Lewellen WG (1974). A Conceptual Reappraisal of Cost of Capital. Financial Management, 3(1): 6370.

Lister R (1983). The cost of retained earnings: A further note, an illustration and a computer program. Journal of Business Finance and Accounting, 10(3): 389-393.

Maness ST (2007). Introduction to Corporate Finance. McGraw-Hill, New York, USA.

Martin JD, Petty JW, Keown AJ and Scott DF (2005). Basic Financial Management. Prentice Hall, New Jersey, USA.

McDaniel WR, McCarty DE and Jessell KA (1996). A note on the calculation of the after-tax cost of debt. International journal of business, 1(1): 7986.

Miller MH and Modigliani F (1966). Some estimates of the cost of capital to the electric utility industry, 1954-57. The American Economic Review, 56(3): 333-391.

Modigliani F and Miller MH (1958). The cost of capital, corporation finance and the theory of investment. The American Economic Review, 48(3): 261-297.

Mpamugo CS (2003). Financial Management. Barloz Publishing, Owerri, Nigeria.

Njoku PNO and Jombo OC (2003). Fundamentals of Business Finance and Financial Management. Barloz Publishing, Owerri, Nigeria.

Nwankwo 0 (2002). Dimensions of Financial Management. Jones Communications, Enugu, Nigeria.

Nwude CJ (2003). Basic principles of financial management: A first course. Nwabude, Enugu, Nigeria.

OLowe RA (1998). Financial management: concepts, financial system, and business finance. Brierly Jones, Lagos, Nigeria.

OLowe RA (2008). Financial management: concepts, financial system, and business finance. Brierly Jones, Lagos, Nigeria. 
Onyendi HU (2004). Financial Management and Policy: Theory, Practice and Institutions. Papen Publisher, Aba, Nigeria.

Pandey IM (1999). Essentials of financial management. Vikas, New Delhi, India.

Patterson CS (1986). Some notes on the cost of new equity: a comment. Journal of Business Finance and Accounting, 13(1): 149-151.

Reilly RR and Wecker WE (1973). On the weighted average cost of capital. Journal of Financial and Quantitative Analysis, 8(01): 123-126.

Ross SA, Westerfield RW and Jaffe J (1996). Corporate Finance, McGraw-Hill, New York, USA.
Samuels JM (1968). An empirical study of the cost of equity capital. Business Ratios, 1(1): 12-15.

Schall $H$ (1973). The theory of financial decision. McGraw-Hill, New York, USA.

Solomon E (1955). Measuring a company's cost of capital. The Journal of Business, 28(4): 240-252.

Uzoka ND (2006). Financial Management. BON, Owerri, Nigeria.

Vickers D (1970). The cost of capital and the structure of the firm. The Journal of Finance, 25(1): 35-46.

Weston JF, Besley S, Brigham EF (1996). Essentials of Managerial Finance. The Dryden Press, New Yourk, USA. 